\title{
Frequency and Timing of Fungicide Applications for the Control of Gray Leaf Spot in Maize
}

J. M. J. Ward, Cedara Agricultural Development Institute, Private Bag X9059, Pietermaritzburg 3200, South Africa; and M. D. Laing and F. H. J. Rijkenberg, Department of Microbiology and Plant Pathology, University of Natal, Private Bag X01, Scottsville, 3209 South Africa

\begin{abstract}
Ward, J. M. J., Laing, M. D., and Rijkenberg, F. H. J. 1997. Frequency and timing of fungicide applications for the control of gray leaf spot in maize. Plant Dis. 81:41-48.

Timing and frequency of fungicide treatments for management and control of gray leaf spot of maize, caused by Cercospora zeae-maydis, were quantified with the logistic model and area under disease progress curve (AUDPC). Control was most effective when spraying commenced as disease severity levels reached 2 to $3 \%$ of the leaf area blighted and when lesions were restricted to the basal five leaves of the maize plant. Highest grain yields were achieved with treatments providing disease control until the crop was physiologically mature. To provide this length of control, the frequency and number of fungicide applications varied with the stage of host development when disease was first apparent; with early infections, more fungicide treatments were necessary to provide protection until physiological maturity. Yield responses to fungicides appeared to be a function of the growth stage of the host when sprays were initiated, the amount of disease at spray date, the length of fungicide control, and effective control through to physiological maturity.
\end{abstract}

Few diseases of major crops have risen from relative obscurity to general recognition as a threat to economical production as suddenly as has gray leaf spot (GLS) of maize (Zea mays L.). GLS is caused by the fungus Cercospora zeae-maydis Tehon \& E. Y. Daniels (10). The disease was first observed in 1988 in KwaZulu-Natal, South Africa, and has since spread rapidly throughout the higher rainfall and irrigated areas of the province. In these areas, it is estimated that $60 \%$ of the commercial crop grown is affected by GLS (14). The pathogen has more recently been observed in major maize-growing areas of neighboring provinces in areas of lower rainfall. This is of great concern to the maize industry. Trials conducted at Cedara Agricultural Development Institute (CADI) near Pietermaritzburg, South Africa, have shown that the disease is capable of reducing grain yields by 20 to $60 \%$ depending on hybrid susceptibility to C. zeae-maydis (13). Fungicides can provide excellent control of the pathogen (13).

Disease progress for GLS is, in general, best described by the logistic model. Progress curves linking the transformed disease severity data points enable the examination of the effects of fungicide treatments on

Corresponding author: J. M. J. Ward

E-mail: jward@cedara1.agric.za

Accepted for publication 15 August 1996.

Publication no. D-1996-1112-05R

(C) 1997 The American Phytopathological Society disease progress. Application of an effective fungicide to foliage interrupts progress of a disease soon after spraying and lasts for an "effective period." This fungicide effective period (FEP) is defined as that during which there is minimal disease increase. The FEP is measured from disease progress curves of the transformed data of each treatment, starting from the time of fungicide application and ending when there is a sharp increase in disease progress (3). This definition differs slightly from the description by Berger (3), who suggested that the treatment effect of a protectant fungicide starts one latent period after spraying, because latent infections are not controlled by protectant fungicides. The discrepancy arises because systemic fungicides, used in this study, control all infections, including latent infections. Characteristics of the theoretical response to fungicide treatment are the sharpness of the swing of the disease into the FEP, zero disease increase during the effective period, and the parallelism of disease progress to the nontreated control (the epidemic delay is equal to the FEP at all subsequent times after the FEP). The FEP is a function of fungicide efficiency, its dose, and the residual breakdown curve (3). With systemic fungicides, the FEP is longer and the disease increase during the FEP is less than with protectant fungicides (3). In practice, when host growth is minimal, which is usual with GLS, as it attacks maize near anthesis, the FEP has a slight upward slant of increasing disease because the fungicide is unable to provide complete control of period, after application of the fungicide, the pathogen (3). The level of disease severity at the time of fungicide treatment affects subsequent disease progress. If disease severity is high at the time of application, the rate of disease increase into FEP is more gradual, the FEP has a steeper slope (greater disease increase), and the FEP is shorter (3). At higher levels of disease, the infection efficiency becomes lower because there is less healthy tissue available for infection, although more inoculum may be present.

This investigation was undertaken to establish the most effective time of application of fungicides and the frequency of sprays necessary for effective control of GLS until physiological maturity.

\section{MATERIALS AND METHODS}

Field study. The study was conducted between 1991 and 1994 at CADI, (29 $32^{\prime} \mathrm{S}, 30^{\circ} 17^{\prime} \mathrm{E}$ ) situated $15 \mathrm{~km}$ north of Pietermaritzburg at an altitude of $1,070 \mathrm{~m}$. The site was north facing and gently sloping, and consisted of well-drained, deep, sandy-clay, loam soils of the Hutton form and Doveton series (8). The trial area had been continuously cropped to maize for the previous 10 years.

The trials were conducted on the same field over the three seasons. The field was no-till seeded into the previous season's maize debris at a seeding rate of 50,000 seeds ha ${ }^{-1}$ with a John Deere 7000 MaxEmerg 4-row planter. Four experiments were planted: on 31 October and 6 December 1991; 5 November 1992; and 26 October 1993. Final plant stands were 45,000 plants $\mathrm{ha}^{-1}$. Fertilizer was applied at a rate sufficient for an 8-ton $\mathrm{ha}^{-1}$ grain crop based on soil analyses and recommendations by the Cedara Fertilizer Advisory Service. Fertilizer was band applied at planting to supply $32 \mathrm{~kg}$ of $\mathrm{N}, 48 \mathrm{~kg}$ of $\mathrm{P}$, $63 \mathrm{~kg}$ of $\mathrm{K}$, and $2.4 \mathrm{~kg}$ of $\mathrm{Zn} \mathrm{ha}{ }^{-1}$. Limestone ammonium nitrate was broadcast when maize was knee-high to provide a further $97 \mathrm{~kg}$ of $\mathrm{N} \mathrm{ha}^{-1}$.

A tank-mix of metolachlor $(1.86 \mathrm{~kg}$ ai $\mathrm{ha}^{-1}$ ) plus atrazine/metolachlor/terbuthylazine $\left(550 / 633 / 550 \mathrm{~g}\right.$ ai ha $\left.{ }^{-1}\right)$ in 300 liters of water $\mathrm{ha}^{-1}$ was applied as a pre-emergent herbicide treatment for the control of grasses and broadleaf weeds. Fenvalerate $\left(28 \mathrm{~g}\right.$ ai ha $\left.{ }^{-1}\right)$ was included in the herbicide tank-mix for the control of cutworm. Carbofuran granules $\left(2.7 \mathrm{~kg}\right.$ ai ha $\left.{ }^{-1}\right)$ were ap- 
plied in the planting furrow for the control of soil insect pests.

Two experiments conducted in the 1991 to 1992 season were split-plot design with four replications. Time of fungicide application was the main plot with hybrids as subplot treatments. Fungicides were applied as single-spray applications made prior to, at, and after anthesis, 53, 67, 89, and 103 days after planting (DAP) in the early planted experiment, and 53, 67, 78, and 90 DAP in the late planted experiment. Two hybrids were planted, National Seeds RS 5206 and Carnia's CRN 4526. RS 5206, previously widely grown in KwaZulu-Natal, is considered to be highly susceptible to GLS, while CRN 4526 is less susceptible. Following results from the
1991 to 1992 experiments, the trial design in the 1992 to 1993 and 1993 to 1994 seasons was changed to a randomized complete block design and only hybrid RS 5206 was used. Treatments consisted of single- and multiple-spray applications. The timing of the sprays commenced at different levels of disease; sprays were initiated when lesions were present on the

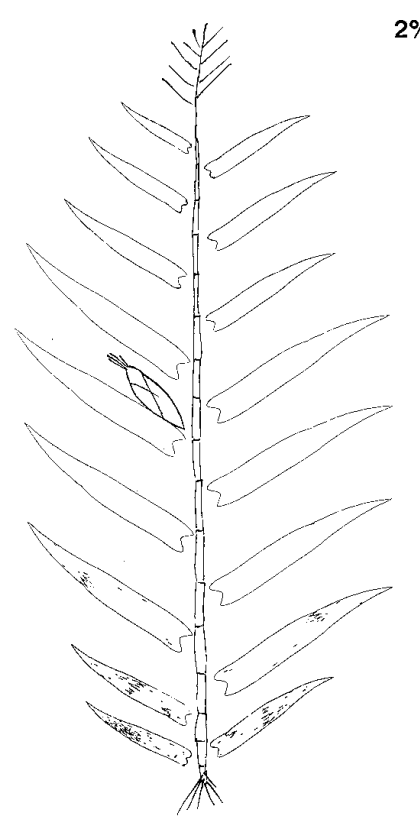

$2 \%$

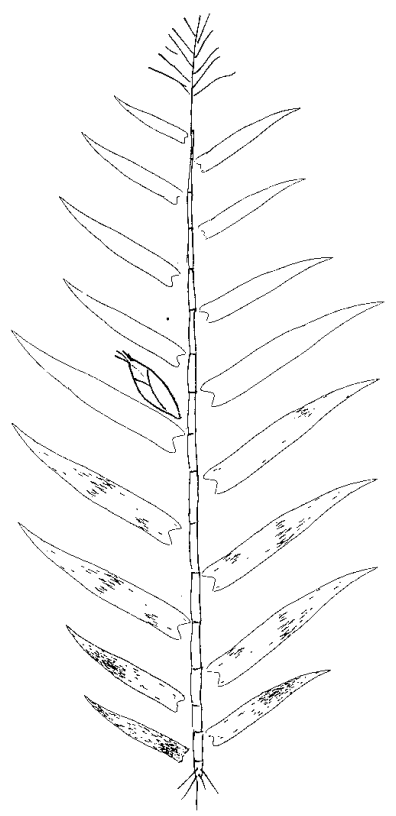

$5 \%$

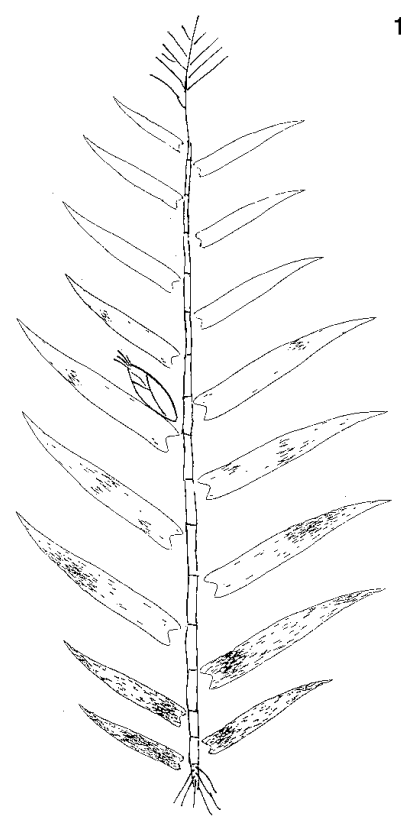

$10 \%$
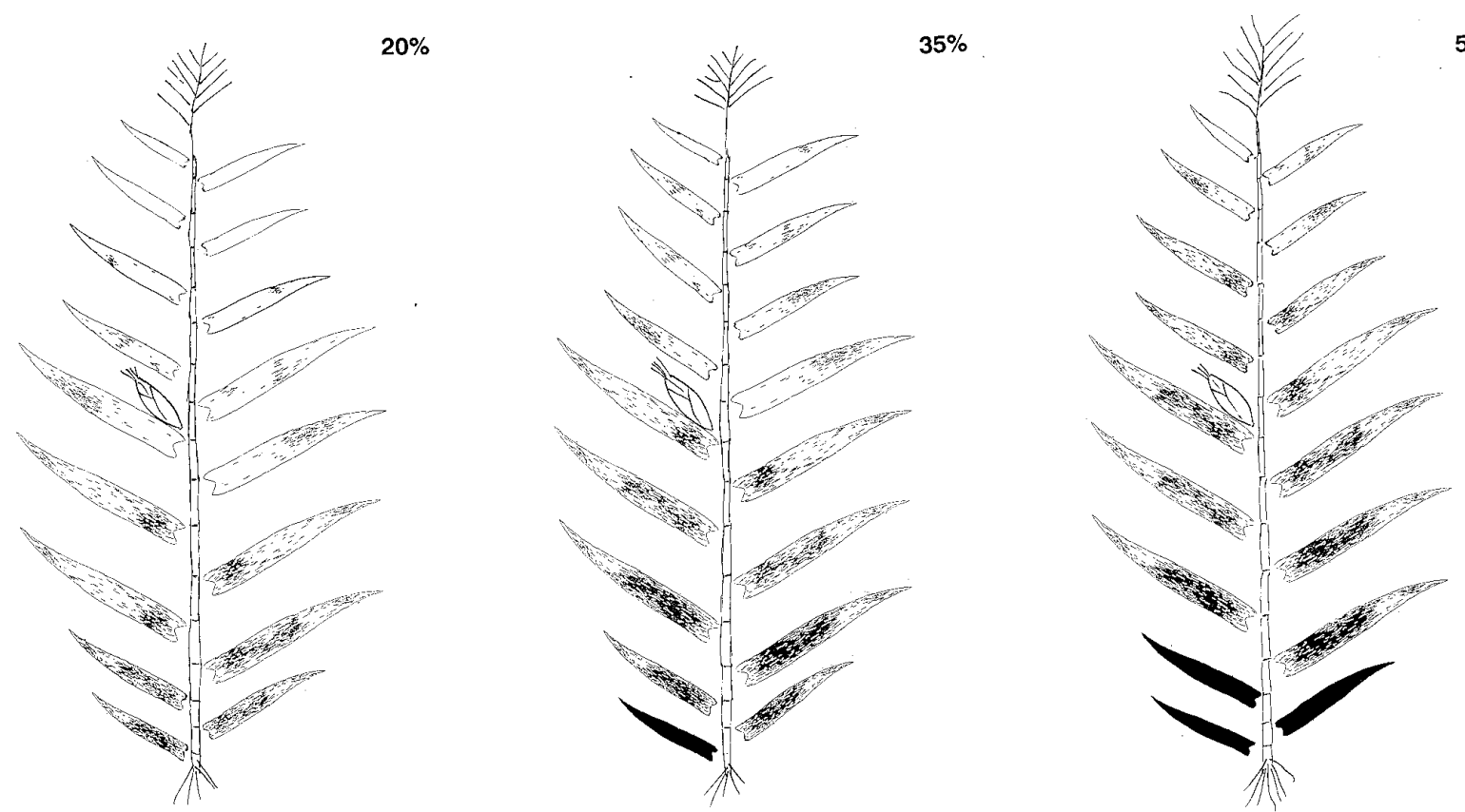

$50 \%$

Fig. 1. Standard assessment diagrams for evaluation of gray leaf spot lesion area on maize. (Percentages given represent the amount of leaf area affected and are indicated by the darkened portion of the leaf). 
basal two leaves, on the basal five leaves, on all basal leaves to ear-height, and on all basal leaves to above ear-height.

Plots consisted of eight rows, spaced $750 \mathrm{~mm}$ apart, and were $12 \mathrm{~m}$ long. Fungicide spray solutions were applied to the four central rows, and the central $10 \mathrm{~m}$ of the two middle rows of the treated area were assessed for disease and harvested for grain yield. The fungicide used in 1991 to 1992 was benomyl at a rate of $375 \mathrm{~g}$ ai ha ${ }^{-1}$ (Benlate 50\% WP, Du Pont de Nemoirs and Coy). In the first season, it was applied in 1,500 liters $\mathrm{ha}^{-1}$ water at $0.15 \mathrm{kPa}$ pressure with a hand-operated Cooper-Peglar back-pack sprayer fitted with a lance and single Spraying Systems TeeJet No 8001 nozzle. In subsequent seasons, a combination of $187.50 \mathrm{~g}$ of carbendazim plus 93.75 $\mathrm{g}$ of flusilazole ai ha ${ }^{-1}$ was applied (Punch Xtra, Du Pont de Nemoirs and Coy) in 500 liters of water, with a $\mathrm{CO}_{2}$-pressurized back-pack sprayer with a vertically mounted spray-boom having three Whirlrain 1/4" WRW2 $-20^{\circ}$ nozzles spaced $1 \mathrm{~m}$ apart.

The dehusked ears from the central two rows of the trial unit were weighed in the field. Subsamples of five or six ears were weighed and shelled in the laboratory, and the shelling percentage determined to calculate the shelled grain mass for each. Moisture content of a 250-g sample of shelled grain was determined and the grain yield was adjusted to $12.5 \%$ moisture content.

Disease assessment. Kranz (7) and Campbell and Madden (4) stressed the importance of standard assessment diagrams as training tools and as guides to improve accuracy and precision in disease assessment. Standard diagrams were developed, based on the standard area diagrams by Smith (10). Leaves of a commonly grown maize hybrid at silking were numbered 1 to 17 for each leaf position from the bottom to the top of the plant. Surface area of each leaf for each leaf position of 20 plants was measured with a LI-COR LI-3100 Area Meter and surface area of an average leaf area for each position was established. Plants in the field showing GLS were examined, starting when only leaves 1 and 2 exhibited visible lesions. These were matched against Smith's standard area diagrams and the percent diseased tissue for each leaf was determined. Calculations with these data and the average surface area for the corresponding leaf position were used to establish the area of diseased tissue, as a percentage of the whole plant. The procedure was repeated as the disease developed on leaves 3,4 , and 5 , and progressively more leaves acropetally, until the entire plant exhibited GLS symptoms. Standard assessment diagrams showing 2, $5,10,20,35$, and $50 \%$ disease were constructed and used as a guide in estimating disease severity (Fig. 1). These data were used to calculate the area under disease progress curve (AUDPC).
The AUDPC, a summary of the disease sons and was calculated from data based on the trapezoidal integration program (2). For making comparisons between epidemics of different time durations, the AUDPC was standardized by dividing the AUDPC value by the total time (days) duration of the epidemic (6).

Statistical analysis. The disease severity data was transformed to fit the logistic model described by Vanderplank (12) and Gompertz (2) in order to linetreatment comparisons, and the measurements of infection rate and FEP. Disease progress, except for the 1991 to 1992 season, was best described by the Vanderplank model (based on comparisons of coefficients of determination $\left[R^{2}\right]$ ), and this model was used in this study. Disease severity, AUDPC, infection rate ( $r$ ), FEP, and grain yield were analyzed by analysis of variance. Mean separations were based epidemic, was used for treatment compariarize the progress curve, thereby allowing

on Duncan's multiple range test at the $5 \%$ level of probability. The analysis was conducted on Genstat 5, version 2.2, Rothamstead Experiment Station, Harpenden, U.K.

\section{RESULTS}

GLS was not observed at CADI prior to the 1991 to 1992 season and inoculum levels in situ were assumed to be relatively low. However, inoculum from debris from the previous crop was sufficient to initiate GLS epidemics in subsequent seasons. GLS was first observed on 4 February, 4 January, and 16 December in the 1991 to 1992, the 1992 to 1993 , and the 1993 to 1994 seasons, respectively. Anthesis was observed 89 and 77 DAP in the 1991 to 1992 experiments and 80 and 78 DAP in the 1992 to 1993 and 1993 to 1994 experiments. respectively. Physiological maturity in these experiments occurred 150, 150, 149, and 153 DAP, respectively.

Table 1. Conditions at Cedara for the maize growing seasons 1991 to 1994

\begin{tabular}{lrrrrrrrr}
\hline Condition & Oct. & Nov. & Dec. & Jan. & Feb. & Mar. & Apr. & Total \\
\hline Rainfall (mm) & & & & & & & & \\
$\quad$ 1991 to 1992 & 209 & 198 & 149 & 105 & 120 & 95 & 51 & 927 \\
$\quad$ 1992 to 1993 & 34 & 83 & 69 & 69 & 108 & 115 & 25 & 503 \\
$\quad$ 1993 to 1994 & 133 & 68 & 162 & 206 & 127 & 113 & 37 & 846 \\
$\quad$ Average & 125 & 116 & 126 & 158 & 130 & 102 & 32 & 789 \\
Mean temperature $\left({ }^{\circ} \mathrm{C}\right)$ & & & & & & & & \\
$\quad$ 1991 to 1992 & 16.1 & 18.3 & 19.7 & 20.4 & 21.0 & 19.8 & 18.9 & \\
$\quad$ 1992 to 1993 & 17.7 & 18.5 & 20.3 & 21.0 & 20.0 & 19.4 & 17.3 & \\
$\quad$ 1993 to 1994 & 17.0 & 18.3 & 19.4 & 19.9 & 19.4 & 19.0 & 17.1 & \\
$\quad$ Average & 17.1 & 18.4 & 19.9 & 20.6 & 20.4 & 19.2 & 17.6 & \\
\hline
\end{tabular}

Table 2. Gray leaf spot (GLS) disease development and grain yield of two maize hybrids for fungicide treatments applied at different dates after planting (DAP) ${ }^{t}$

\begin{tabular}{|c|c|c|c|c|c|c|}
\hline \multirow{3}{*}{$\begin{array}{l}\text { Hybrid/ } \\
\text { treatment date }\end{array}$} & \multirow{3}{*}{$\begin{array}{c}\text { Fungicide } \\
\text { applied (DAP) }\end{array}$} & \multicolumn{4}{|c|}{ Disease severity $(\%)^{\mathrm{u}}$} & \multirow{3}{*}{$\begin{array}{c}\text { Grain yield } \\
\left(\mathrm{kg} \mathrm{ha}^{-1}\right)\end{array}$} \\
\hline & & \multicolumn{2}{|c|}{ Assessment (DAP) } & \multirow[b]{2}{*}{$r^{v}$} & \multirow[b]{2}{*}{ SAUDPC $^{w}$} & \\
\hline & & 121 & 134 & & & \\
\hline \multicolumn{7}{|l|}{ RS $5206^{x}$} \\
\hline Nonsprayed & $\ldots$ & $22 \mathrm{a}^{\mathrm{y}}$ & $91 \mathrm{a}$ & $28.4 \mathrm{a}$ & $56 \mathrm{a}$ & $6,177 \mathrm{~b}$ \\
\hline 23 December & 53 & $24 \mathrm{a}$ & $86 \mathrm{a}$ & $23.5 \mathrm{a}$ & $55 \mathrm{a}$ & $5,898 \mathrm{~b}$ \\
\hline 6 January & 67 & $4 \mathrm{~b}$ & $55 \mathrm{~b}$ & $27.8 \mathrm{a}$ & $30 \mathrm{~b}$ & 8,480 a \\
\hline 28 January & 89 & $1 \mathrm{~b}$ & $16 \mathrm{c}$ & $24.0 \mathrm{a}$ & $9 \mathrm{c}$ & $9,689 \mathrm{a}$ \\
\hline 11 February & 103 & $2 \mathrm{~b}$ & $5 \mathrm{~d}$ & $6.3 \mathrm{~b}$ & $4 \mathrm{c}$ & $8,686 \mathrm{a}$ \\
\hline Mean & & & & & & $7,786^{\mathrm{z}}$ \\
\hline \multicolumn{7}{|l|}{ CRN $452^{x}$} \\
\hline Nonsprayed & & $16 \mathrm{c}$ & $91 \mathrm{a}$ & $31.6 \mathrm{c}$ & $54 \mathrm{e}$ & $3,557 \mathrm{c}$ \\
\hline 23 December & 53 & $16 \mathrm{c}$ & $85 \mathrm{a}$ & $27.6 \mathrm{c}$ & $51 \mathrm{e}$ & $3,875 \mathrm{bc}$ \\
\hline 6 January & 67 & $3 \mathrm{~d}$ & $50 \mathrm{~b}$ & $27.3 \mathrm{c}$ & $27 \mathrm{f}$ & $4,575 \mathrm{~b}$ \\
\hline 28 January & 89 & $1 \mathrm{~d}$ & $13 \mathrm{c}$ & $21.2 \mathrm{~d}$ & $7 \mathrm{~g}$ & $4,838 \mathrm{a}$ \\
\hline 11 February & 103 & $4 \mathrm{~d}$ & $2 \mathrm{~d}$ & $4.1 \mathrm{e}$ & $3 \mathrm{~g}$ & $5,360 \mathrm{a}$ \\
\hline Mean & & & & & & $4,441^{\mathrm{z}}$ \\
\hline SE (of a mean) & & 1.5 & 3.3 & 3.0 & 1.8 & 363.8 \\
\hline Grand mean & & 9.5 & 49.6 & 21.4 & 29.5 & 6,113 \\
\hline $\mathrm{CV} \%$ & & 22.0 & 9.0 & 19.2 & 10.5 & 11.6 \\
\hline
\end{tabular}

${ }^{t}$ Planted 31 October 1991.

" Disease severity is percent leaf tissue with symptoms of GLS

${ }^{\mathrm{v}}$ Infection rate $\times 100$, calculated by regressing the logistic transformation on time (DAP).

${ }^{\mathrm{w}}$ Standardized area under disease progress curve.

${ }^{x}$ Anthesis occurred 89 days after planting.

${ }^{y}$ Means within a column having letters in common do not differ significantly $(P<0.05)$ according to Duncan's multiple range test.

${ }^{\mathrm{z}}$ The grain yield of RS 5206 was significantly greater $(P<0.001)$ than that of CRN 4526 . 
Weather conditions varied over the seasons in which trials were conducted (Table 1). Growing conditions in 1991 to 1992 were warm and moist during the vegetative growth stages of maize but, after anthesis, rainfall declined. During grainfill, days were warm to hot and heavy dews favoring disease were frequent. The 1992 to 1993 season was dry, with only $63 \%$ of the average rainfall recorded during the growing season. In contrast, the rainfall in 1993 to 1994 was above average and well distributed throughout the growing season. Temperatures were lower than average during grainfill and mists were frequent, especially during January and February 1994.

1991 to 1992 season. Disease was first observed in the early and late planted experiments 95 and 60 DAP, respectively. The fungicide treatments applied soon after disease was first observed in both plantings, on 11 February, provided among the most effective control of disease (AUDPC) and among the highest grain yields (Tables 2 and $3)$. As a result of more disease observations in the late planted experiment (6 December 1991), presentation of additional results is confined to this experiment (Table 3 ).

Initial disease progress was slow, with disease severity of nonsprayed treatments increasing in the first 26 days from 1 to $8 \%$ in RS 5206 and from 1 to $3 \%$ in CRN 4526. Subsequent progress was rapid: disease severity increased in the following 30 days from 8 to $88 \%$ in RS 5206 and from 3 to $80 \%$ in CRN 4526 (Table 3).
Although there was on average higher disease (AUDPC) for RS 5206 than for CRN 4526, RS 5206 had on average higher grain yields $\left(6,480 \mathrm{~kg} \mathrm{ha}^{-1}\right)$ than CRN $4526\left(5,384 \mathrm{~kg} \mathrm{ha}^{-1}\right)$ (Table 3). There was lower disease (AUDPC) with fungicide treatments of both hybrids than with the nonsprayed treatments, and this was reflected in highly significant grain yield responses to fungicides. The fungicide treatment initiated on 11 February, 7 days after disease was first observed, had the lowest disease (AUDPC $=19$ ) and the longest FEP (39 days) in RS 5206, and had among the lowest disease (AUDPC $=16$ ) and longest FEP (32 days) in CRN 4526. This treatment, 67 DAP, also had the highest grain yields in both hybrids although these were not significantly different from those with fungicide treatments applied later.

The fungicide treatment applied at 53 DAP, 2 weeks before disease was observed, had higher final disease severity, higher AUDPC, higher infection rate, shorter FEP, and lower grain yield than the fungicide treatment applied at 67 DAP. Treatment later, at 90 DAP, when there was relatively higher final disease severity, also had higher AUDPC and shorter FEP, and, with CRN 4526, had lower grain yield than treatment at 67 DAP (Table 3).

1992 to 1993 season. Despite unfavorable weather conditions for disease during the vegetative growth stage of the crop, GLS symptoms were observed before an- thesis, 60 DAP. Initial disease development was slow, with disease in the nonsprayed treatment rising to $7.8 \%$ severity 36 days after first symptoms were observed. Subsequent progress was rapid, with severity increasing to $60 \%$ in the following 21 days (Table 4).

All fungicide treatments provided significant reduction in disease (AUDPC) and reduced the infection rate (Table 4). Fungicides provided effective control of disease up to 118 DAP, but did not provide control through to physiological maturity at 149 DAP. Disease progress following the FEP was normal and paralleled that in the nonsprayed treatment (Fig. 2B). Multiplespray treatments resulted in longer FEP (41 to 52 days) than single-spray treatments (26 to 33 days). The spray treatment initiated at 83 DAP; when the basal five leaves of the host were symptomatic, provided the longest FEP (33 days) of the single-spray treatments.

1993 to 1994 season. Climatic conditions were favorable for GLS and disease was first observed earlier (53 DAP) than in the previous season (60 DAP). Disease progress followed a trend similar to that in previous seasons, with initial slow disease progress (up to $2 \%$ disease in 40 days) followed by rapid progress, reaching $71 \%$ severity in the following 36 days.

All fungicide treatments reduced disease severity, by 147 DAP, shortly before the crop was physiologically mature (Table 5). Fungicides also reduced overall disease

Table 3. Gray leaf spot (GLS) disease development, effective periods of fungicide control, and grain yields of two maize hybrids, for fungicide treatments applied at different dates after planting (DAP) ${ }^{\mathrm{p}}$

\begin{tabular}{|c|c|c|c|c|c|c|c|c|c|c|c|c|}
\hline \multirow{3}{*}{$\begin{array}{l}\text { Hybrid/ } \\
\text { treatment date }\end{array}$} & \multirow{3}{*}{$\begin{array}{l}\text { Fungic. appl. } \\
\text { (DAP) }\end{array}$} & \multicolumn{5}{|c|}{ Disease severity $(\%)^{\mathrm{r}}$} & \multirow[b]{3}{*}{ SAUDPC $^{s}$} & \multirow[b]{3}{*}{$r^{\mathrm{t}}$} & \multirow[b]{3}{*}{$R^{2 u}$} & \multicolumn{2}{|c|}{ Effective period } & \multirow{3}{*}{$\begin{array}{r}\text { Grain yield } \\
\left(\text { kgha }^{-1}\right)\end{array}$} \\
\hline & & \multirow{2}{*}{$\begin{array}{c}\text { At treat- } \\
\text { ment date }\end{array}$} & \multicolumn{4}{|c|}{ Assessment (DAP) } & & & & Length & Period end & \\
\hline & & & 86 & 99 & 116 & 140 & & & & in days ${ }^{v}$ & (DAP) & \\
\hline \multicolumn{13}{|l|}{ RS 5206 } \\
\hline Nonsprayed & & & 8 & $55 \mathrm{a}^{\mathrm{x}}$ & $88 \mathrm{a}$ & $100 \mathrm{a}$ & $68 \mathrm{a}$ & $13.1 \mathrm{a}$ & 0.977 & . & & $4,101 \mathrm{c}$ \\
\hline 28 January & 53 & 0 & 1 & $33 \mathrm{~b}$ & $73 \mathrm{~b}$ & 99 a & $58 \mathrm{~b}$ & $15.9 \mathrm{a}$ & 0.961 & $14 \mathrm{c}$ & 63 & $5,524 \mathrm{~b}$ \\
\hline 11 February & 67 & 1.5 & 2 & $1 \mathrm{c}$ & $5 \mathrm{e}$ & $69 \mathrm{bc}$ & $19 \mathrm{c}$ & $9.8 \mathrm{~b}$ & 0.827 & $39 a$ & 104 & 7,929 a \\
\hline 21 February & 78 & 5.7 & 5 & $18 \mathrm{c}$ & $16 \mathrm{~d}$ & $83 a b$ & $28 \mathrm{~d}$ & $8.8 \mathrm{~b}$ & 0.878 & $26 \mathrm{~b}$ & 104 & 7,770 a \\
\hline 6 March & 90 & 21.5 & 10 & $42 \mathrm{~b}$ & $35 \mathrm{c}$ & $63 \mathrm{c}$ & $34 \mathrm{~d}$ & $4.5 \mathrm{c}$ & 0.752 & $17 \mathrm{c}$ & 107 & $7,075 \mathrm{a}$ \\
\hline Mean & & & & & & & $42^{y}$ & & & & & $6,480^{z}$ \\
\hline \multicolumn{13}{|l|}{ CRN $4526^{w}$} \\
\hline Nonsprayed & & & 3 & $49 \mathrm{~d}$ & $80 \mathrm{f}$ & $100 \mathrm{~d}$ & $63 \mathrm{~d}$ & $14.1 \mathrm{e}$ & 0.966 & & & $3,463 \mathrm{f}$ \\
\hline 28 January & 53 & 0 & 1 & $14 \mathrm{f}$ & $56 \mathrm{~g}$ & $100 \mathrm{~d}$ & $50 \mathrm{c}$ & $16.6 \mathrm{f}$ & 0.997 & $15 \mathrm{e}$ & 59 & $5,177 \mathrm{e}$ \\
\hline 11 February & 67 & 0.5 & 2 & $1 \mathrm{~g}$ & $3 i$ & $64 \mathrm{e}$ & $16 \mathrm{~b}$ & $8.8 \mathrm{~h}$ & 0.879 & $32 \mathrm{~d}$ & 99 & $6,551 \mathrm{~d}$ \\
\hline 21 February & 78 & 2.1 & 2 & $4 \mathrm{~g}$ & $10 \mathrm{i}$ & $71 \mathrm{e}$ & $21 \mathrm{ab}$ & $8.8 \mathrm{gh}$ & 0.976 & $25 \mathrm{~d}$ & 104 & $6,364 \mathrm{~d}$ \\
\hline 6 March & 90 & 9.8 & 6 & $35 \mathrm{e}$ & $25 \mathrm{~h}$ & $56 \mathrm{e}$ & $27 \mathrm{a}$ & $4.6 \mathrm{~g}$ & 0.846 & $17 \mathrm{e}$ & 107 & $5,387 \mathrm{e}$ \\
\hline Mean & & & & & & & $36^{y}$ & & & & & $5,384^{z}$ \\
\hline SE (of a mean) & & & & 3.0 & 3.6 & 5.3 & 2.5 & 1.6 & & 2.4 & & 280.6 \\
\hline Grand mean & & & & 23.9 & 39.0 & 80.4 & 38.6 & 11.4 & & 23.1 & & 5,932 \\
\hline CV \% & & & & 13.6 & 7.8 & 5.5 & 5.4 & 26.8 & & 16.0 & & 8.7 \\
\hline
\end{tabular}

p Planted 6 December 1991.

q Disease severity from logistic progress curves.

${ }^{\mathrm{r}}$ Disease severity is percent leaf tissue with symptoms of GLS.

s Standardized area under disease progress curve.

${ }^{\mathrm{t}}$ Infection rate $\times 100$, calculated by regressing the logistic transformation on time (DAP)

u Coefficient of determination.

${ }^{v}$ Calculated from logistic progress curves.

${ }^{\text {w}}$ Disease first observed 60 DAP, anthesis occurred 77 DAP, and physiological maturity at 150 DAP

${ }^{x}$ Means within a column having letters in common do not differ significantly $(P \leq 0.05)$ according to Duncan's multiple range test.

y AUDPC values for RS 5206 and CRN 4526 were significantly $(P<0.001)$ different.

${ }^{\mathrm{z}}$ Grain yield of RS 5206 was significantly higher than that of CRN $4526(P<0.001)$. 
(AUDPC) for all treatments, except the single-spray treatment 2 (beginning 88 DAP when lesions were present on the basal two leaves), compared with the nonsprayed treatment. The reduction in disease by fungicide treatment was reflected in significant grain yield responses.

Time of application and number of spray treatments under conditions favorable for disease development in 1993 to 1994 contributed to large differences in disease severity, length of the FEP, and grain yields harvested. The three-spray and two-spray programs, except for treatment 8 (beginning at higher initial disease severity, 107 DAP), provided significantly better control of disease (AUDPC) and longer FEP than did the single-spray and nonsprayed treatments. This improved disease control was also reflected in the higher grain yields achieved by these treatments.

Spray treatment 2, (beginning 93 DAP when disease was $2 \%$ on the basal five leaves), provided the lowest disease (AUDPC $=32$ ) of the single-spray treatments and had the longest FEP (29 days), although this was not reflected in higher grain yields. Treatment 7, initiated 93 DAP when lesions were on the basal five leaves, also had the lowest disease (AUDPC $=9$ ) and longest FEP (54 days), and among the highest grain yields, of the two-spray treat- ments. The three-spray program provided control of disease (AUDPC) similar to that of treatment 7. Although the three-spray treatment provided the longest FEP, it was not significantly different from treatment 7. The three-spray treatment also produced the highest grain yield, but yield was not significantly higher than that with other, two-spray, treatments except treatment 8 .

Only the multiple-spray treatments and treatment 5 reduced infection rates. The remaining single-spray treatments had infection rates similar to or higher than that of the nonsprayed treatment.

\section{DISCUSSION}

Farmers in KwaZulu-Natal receive approximately US\$139 ton ${ }^{-1}$ for maize. Farmers who normally harvest 5 tons of grain ha ${ }^{-1}$ can lose between 1 and 3 tons of grain $\mathrm{ha}^{-1}$ from GLS. The cost of fungicide is US\$ $25 \mathrm{ha}^{-1}$ and the cost of aerial application is US\$11 ha ${ }^{-1}$, making a total cost for control of US\$36 ha $\mathrm{h}^{-1}$. The break-even increase in grain yield is therefore $259 \mathrm{~kg}$ $\mathrm{ha}^{-1}$. Responses to single-spray treatments varied between 875 and $2,705 \mathrm{~kg} \mathrm{ha}^{-1}$, to two sprays were between 1,310 and 4,334 $\mathrm{kg} \mathrm{ha}^{-1}$, and to three sprays were between 2,020 and 4,691 $\mathrm{kg} \mathrm{ha}^{-1}$. Cost of fungicide treatments was therefore economically justified.
Yield is a function of photosynthesis carried out by the plant and is related to the leaf area and its duration after flowering (5). The top eight or nine leaves contribute 75 to $90 \%$ to grainfill (1). Further, the number of kernels on the ear is established at anthesis (9). It is therefore important to maintain the upper leaves in a healthy condition until physiological maturity, if maximum yields are to be achieved. Foliar diseases such as GLS can, under favorable conditions, result in extensive leaf blighting, leading to loss in grain yield. The loss in photosynthetic area also causes depletion of carbohydrate from the stalk in an attempt by the plant to meet the demands of grain filling, and predisposes the plants to stalk-lodging, exacerbating the yield losses due to GLS (11).

In the 3 years of studies at CADI, GLS was observed in the crop well before anthesis. However, the disease was characteristically slow to develop and its main effect on yield loss was primarily a reduction in grainfill rather than in the number of kernels determined at anthesis. The trials consistently indicated that fungicide treatments were effective in delaying the leaf blighting process and those treatments with the longest FEP usually resulted in the highest grain yield.

Time and frequency of application of

Table 4. Gray leaf spot (GLS) disease development, effective periods of fungicide control, and grain yields, for fungicide treatments applied at different stages of disease development (1992 to 1993 season)

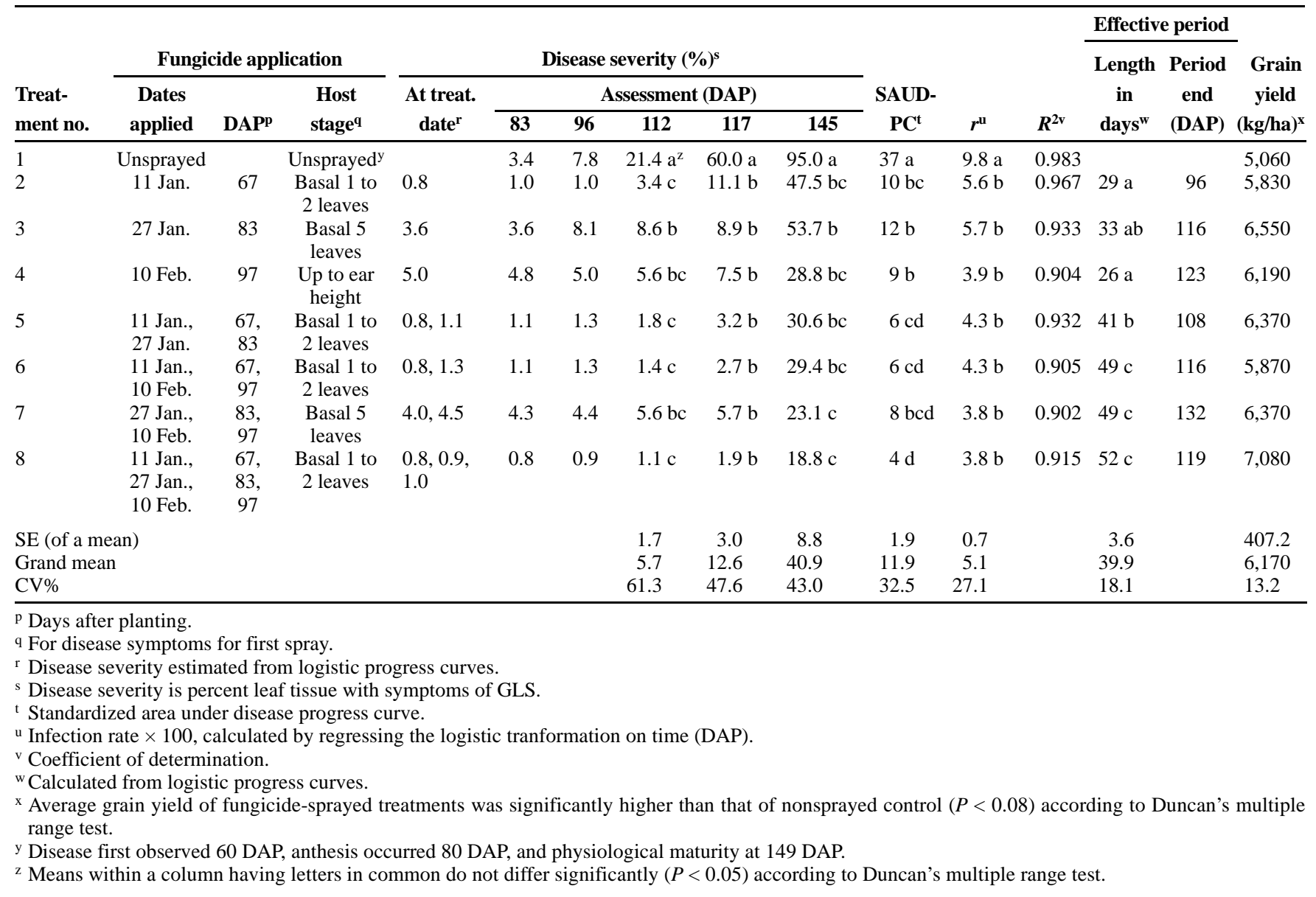


fungicide treatments were critical to the length of the FEP. It is customary to begin a fungicide program as early as possible after detectable levels of disease develop. With the characteristically slow initial development of GLS disease, it is not easy to define the stage of "detectable level" of disease when spraying should commence.
Certainly the 1991 to 1992 studies indicated that spray applications beginning before GLS was observed were less effective, while applications made after the pathogen had begun to rapidly increase were also less effective in controlling the epidemic. These early experiments indicated that treatment should be initiated af- ter the disease was observed but before high levels were present. Subsequent trials confirmed this conclusion.

Spray applications initiated when disease had progressed to the basal five leaves of maize usually provided the longest FEPs and highest grain yields of the single-spray treatments, but FEPs were of insufficient
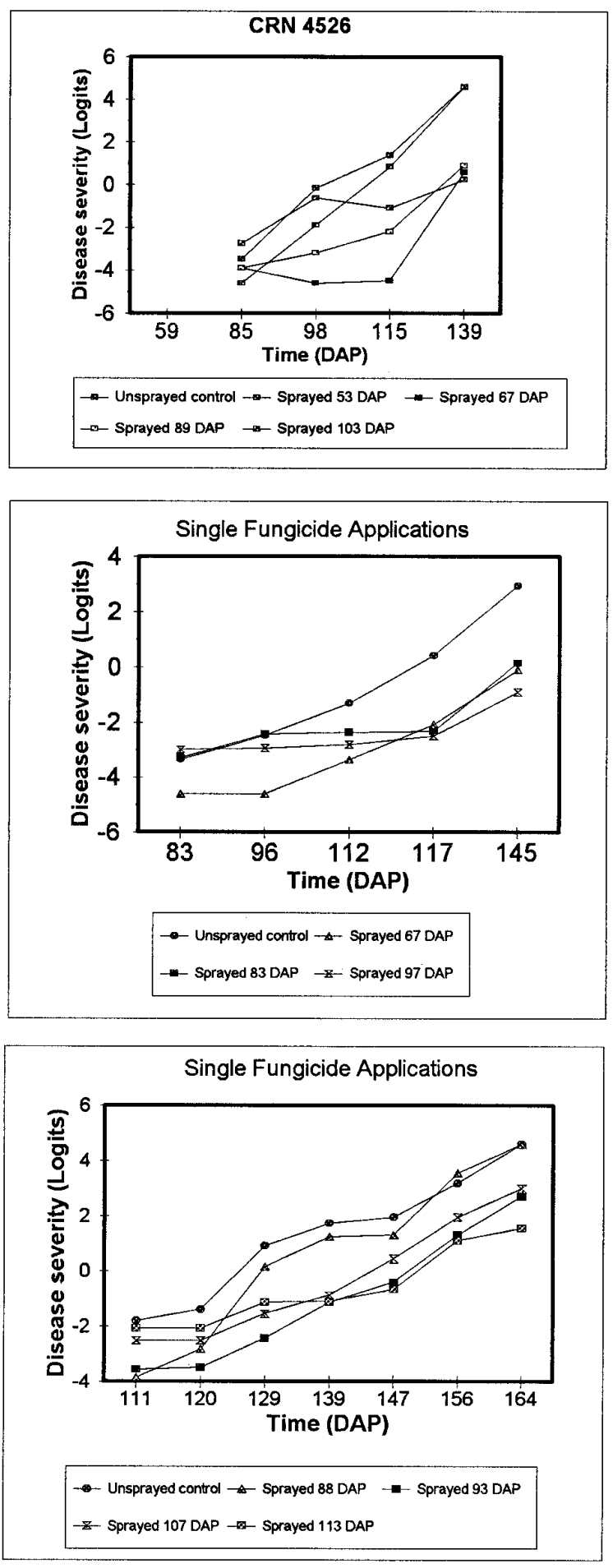

A

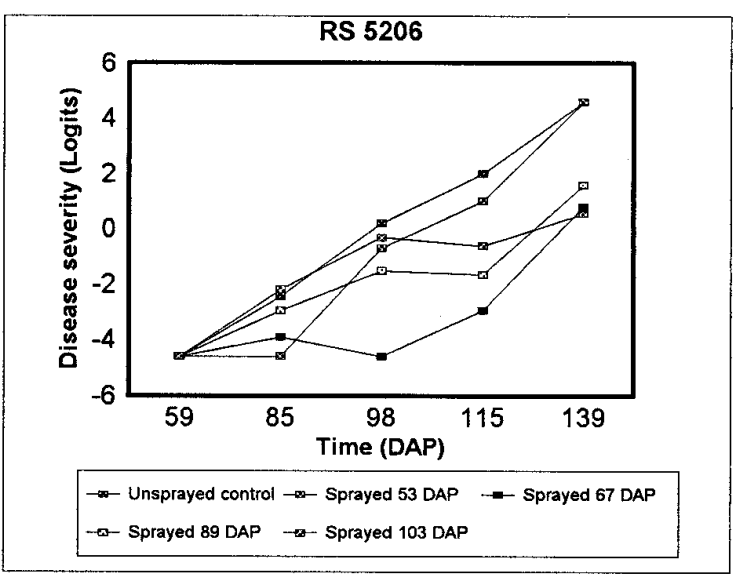

B

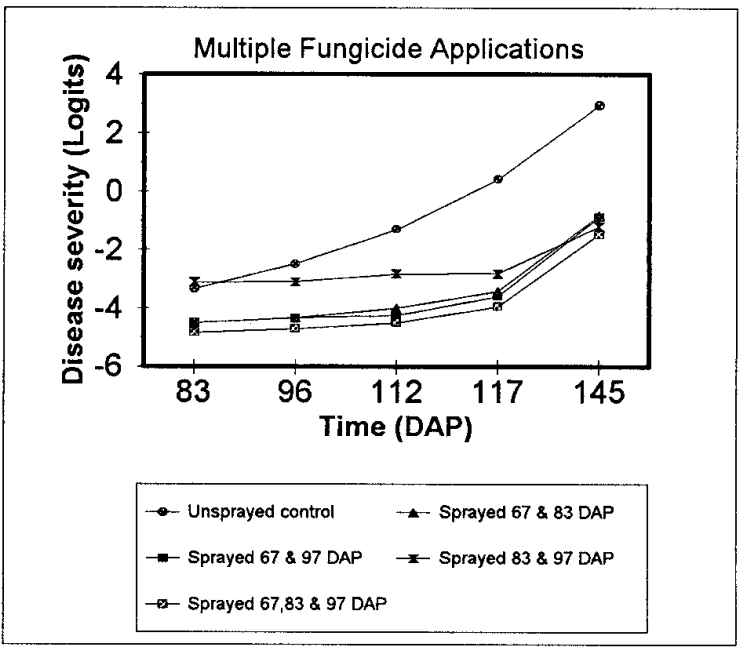

C

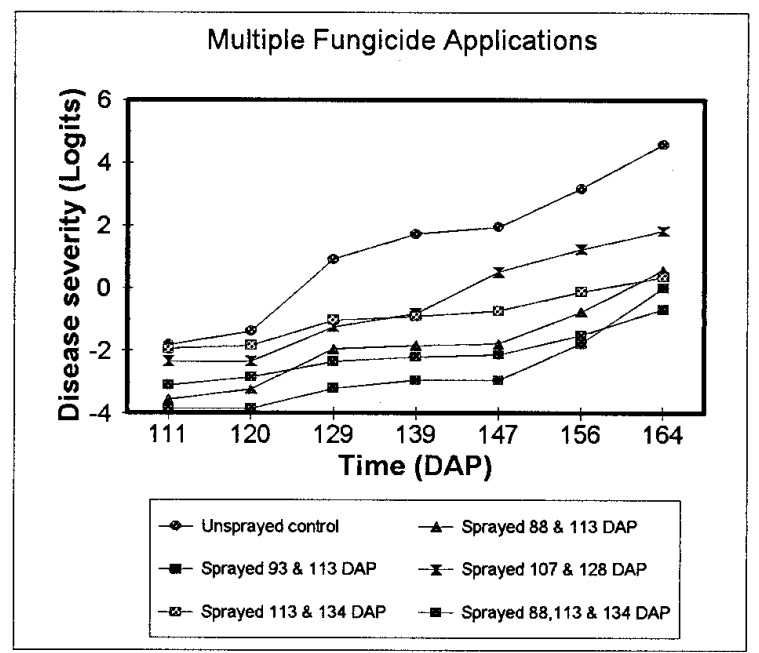

Fig. 2. Logistic models of disease progress of gray leaf spot disease severity of fungicide treatments applied at different times of application against time for (A) 1991 to 1992, (B) 1992 to 1993, and (C) 1993 to 1994. 
duration to protect the crop until it was physiologically mature. The multiple-spray treatments, with a longer combined FEP, delayed the development of disease longer, and resulted in better disease control and higher grain yields than single-spray treatments. Further, the number of basal leaves affected when the fungicide treatment was initiated played an important role in determining the length of control. This point is clearly shown in the 1993 to 1994 data, when two well-timed sprays, commencing when disease was $2 \%$ and present on the basal five leaves, provided control of disease as effective as the three-spray program commencing at lower disease ratings with disease present on the basal two leaves. The difference in yield between the two treatments was not significant $(P \leq$ 0.05).

The importance of controlling disease through to physiological maturity was demonstrated. The relatively long period after breakdown in fungicide control until physiological maturity in the three-spray program in 1992 to 1993 resulted in a relatively small increase (29\%) in grain yield. This long period after fungicide breakdown may explain the lack of significance be- tween treatments in grain yield, in spite of significant differences in control of disease (AUDPC). In contrast, the three-spray treatment in 1993 to 1994 provided effective disease control until after physiological maturity and resulted in a $68 \%$ increase in grain yield. The object, therefore, of any spray program must be to delay disease in maize through to physiological maturity.

The trials determined that the optimum time to commence fungicide treatment is when the disease level is between 2 and $3 \%$ and lesions are visible on the basal five leaves of the plant. Further sprays may be necessary to provide control until the crop is physiologically mature. Spray intervals depend on duration of weather conditions favorable for disease, and results from the trials indicate that this interval may vary between 20 and 30 days. Yield responses to fungicide treatments appear to be a function of the growth stage when sprays are initiated, the amount of disease at spray date, the FEP, and control through to physiological maturity.

Experiments were conducted with the GLS-susceptible hybrid RS 5206. Resistance appears to be of a rate-reducing type, and less susceptible hybrids may react dif- ferently to the timing and number of spray applications. Finally, the trials were conducted with equipment that provided fullcover spray application up to 450 liters $\mathrm{ha}^{-1}$. Such medium-volume applications may not be feasible in commercial agriculture and more research is required on different methods of application and spray volumes, including low-volume aerial application.

\section{ACKNOWLEDGMENTS}

We thank Margie Whitwell for statistical assistance, and Pat Caldwell and Andy Cairns for editing the manuscript.

\section{LITERATURE CITED}

1. Allison, J. C. S., and Watson, D. J. 1966. The production and distribution of dry matter in maize after flowering. Ann. Bot. N.S. 30:365381.

2. Berger, R. D. 1981. Comparison of Gompertz and logistic equations to describe plant disease progress. Phytopathology 71:716-719.

3. Berger, R. D. 1987. The analysis of the effects of control measures on the development of epidemics. Pages 137-151 in: Experimental Techniques in Plant Disease Epidemiology. J. Kranz and J. Rotem, eds. Springer-Verlag, New York.

4. Campbell, C. L., and Madden, L. V. 1990. Introduction to Plant Disease Epidemiology.

Table 5. Gray leaf spot (GLS) disease development, effective periods of fungicide control, and grain yields, for fungicide treatments applied at different stages of disease development (1993 to 1994 season)

\begin{tabular}{|c|c|c|c|c|c|c|c|c|c|c|c|c|c|c|c|c|c|}
\hline \multirow{4}{*}{$\begin{array}{l}\text { Treat- } \\
\text { ment no. }\end{array}$} & & & & \multicolumn{8}{|c|}{ Disease severity $(\%)^{\mathrm{t}}$} & \multirow{4}{*}{$\begin{array}{l}\text { SAU- } \\
\text { DPC }^{\text {u }}\end{array}$} & \multirow[b]{4}{*}{$r^{v}$} & \multirow[b]{4}{*}{$R^{2 \mathrm{w}}$} & \multicolumn{2}{|c|}{$\begin{array}{c}\begin{array}{c}\text { Effective } \\
\text { period }\end{array} \\
\end{array}$} & \multirow{4}{*}{$\begin{array}{c}\text { Grain } \\
\text { yield } \\
\text { (kg/ha) }\end{array}$} \\
\hline & \multicolumn{3}{|c|}{ Fungicide application } & \multirow{3}{*}{$\begin{array}{c}\text { At } \\
\text { treat. } \\
\text { date }^{\mathrm{s}}\end{array}$} & \multirow{2}{*}{\multicolumn{7}{|c|}{ Assessment (DAP) }} & & & & Length & Period & \\
\hline & \multirow{2}{*}{$\begin{array}{c}\text { Dates } \\
\text { applied }\end{array}$} & \multirow[b]{2}{*}{ DAPq } & \multirow{2}{*}{$\begin{array}{c}\text { Host } \\
\text { stage }^{r}\end{array}$} & & & & & & & & & & & & in & end & \\
\hline & & & & & 111 & 120 & 129 & 139 & 147 & 156 & 164 & & & & days $^{x}$ & (DAP) & \\
\hline 1 & & & $\begin{array}{c}\text { Non- } \\
\text { sprayed }\end{array}$ & $\ldots$ & 14.1 & 20.0 & 71.3 & 85.0 & $87.5 \mathrm{a}^{\mathrm{y}}$ & $96.0 \mathrm{a}$ & $99.0 \mathrm{a}$ & $69 a$ & $12.1 \mathrm{~b}$ & 0.98 & $\ldots$ & $\ldots$ & $2,266 a^{*}$ \\
\hline 2 & 22 Jan. & 88 & $\begin{array}{l}\text { Basal } 2 \\
\text { leaves }^{\mathrm{z}}\end{array}$ & 1.5 & 2.1 & 5.6 & 53.8 & 77.5 & $78.8 \mathrm{~b}$ & $97.2 \mathrm{~b}$ & $99.0 \mathrm{a}$ & $60 \mathrm{a}$ & $16.0 \mathrm{a}$ & 0.98 & $22 \mathrm{fg}$ & 110 & $3,141 \mathrm{ab}$ \\
\hline 3 & 27 Jan. & 93 & $\begin{array}{c}\text { Basal } 5 \\
\text { leaves }\end{array}$ & 2.0 & 2.8 & 3.0 & 8.1 & 24.4 & $40.0 \mathrm{c}$ & $78.7 \mathrm{c}$ & $93.7 \mathrm{ab}$ & $32 \mathrm{~cd}$ & $12.5 \mathrm{~b}$ & 0.98 & 29 ef & 122 & $4,211 b c$ \\
\hline 4 & $10 \mathrm{Feb}$. & 107 & $\begin{array}{l}\text { Up to ear } \\
\text { height }\end{array}$ & 10.0 & 7.5 & 7.5 & 17.5 & 29.4 & $39.4 \mathrm{c}$ & $87.5 \mathrm{c}$ & $95.2 \mathrm{ab}$ & $38 \mathrm{~b}$ & $11.0 \mathrm{~b}$ & 0.95 & $18 \mathrm{gh}$ & 125 & $4,033 \mathrm{bc}$ \\
\hline 5 & 16 Feb. & 113 & $\begin{array}{c}\text { Above ear } \\
\text { height }\end{array}$ & 14.0 & 11.3 & 11.3 & 24.4 & 25.0 & $33.8 \mathrm{c}$ & $75.0 \mathrm{c}$ & $82.5 \mathrm{~b}$ & $35 \mathrm{bc}$ & $7.4 \mathrm{~cd}$ & 0.94 & $13 \mathrm{~h}$ & 126 & $4,971 \mathrm{c}$ \\
\hline 6 & $\begin{array}{l}22 \text { Jan., } \\
16 \text { Feb. }\end{array}$ & $\begin{array}{l}88, \\
113\end{array}$ & $\begin{array}{c}\text { Basal } 2 \\
\text { leaves }\end{array}$ & $\begin{array}{l}1.5, \\
3.1\end{array}$ & 2.8 & 3.8 & 12.5 & 13.8 & $14.4 \mathrm{~d}$ & $31.9 \mathrm{~d}$ & $63.7 \mathrm{c}$ & $17 \mathrm{e}$ & $7.3 \mathrm{~cd}$ & 0.96 & $36 \mathrm{de}$ & 124 & $6,525 \mathrm{~d}$ \\
\hline 7 & $\begin{array}{l}27 \text { Jan., } \\
16 \text { Feb. }\end{array}$ & $\begin{array}{l}93 \\
113\end{array}$ & $\begin{array}{l}\text { Basal } 5 \\
\text { leaves }\end{array}$ & $\begin{array}{l}2.0 \\
2.0\end{array}$ & 2.1 & 2.1 & 3.9 & 5.0 & $5.0 \mathrm{e}$ & $14.4 \mathrm{e}$ & $50.0 \mathrm{~d}$ & $9 \mathrm{f}$ & $6.5 \mathrm{~d}$ & 0.89 & $54 \mathrm{~b}$ & 147 & $6,600 \mathrm{~d}$ \\
\hline 8 & $\begin{array}{l}10 \text { Feb., } \\
3 \text { Mar. }\end{array}$ & $\begin{array}{l}107 \\
128\end{array}$ & $\begin{array}{l}\text { Up to ear } \\
\text { height }\end{array}$ & $\begin{array}{l}10.0 \\
20.0\end{array}$ & 8.8 & 8.8 & 22.5 & 30.6 & $37.5 \mathrm{c}$ & $77.5 \mathrm{c}$ & $86.2 \mathrm{ab}$ & $37 \mathrm{bc}$ & $8.4 \mathrm{c}$ & 0.97 & $38 \mathrm{~cd}$ & 145 & $4,389 \mathrm{bc}$ \\
\hline 9 & $\begin{array}{l}16 \text { Feb., } \\
9 \text { Mar. }\end{array}$ & $\begin{array}{l}113, \\
134\end{array}$ & $\begin{array}{c}\text { Above ear } \\
\text { height }\end{array}$ & $\begin{array}{l}14.0 \\
26.0\end{array}$ & 12.5 & 13.8 & 26.3 & 28.8 & $32.5 \mathrm{c}$ & $46.9 \mathrm{c}$ & $58.7 \mathrm{~cd}$ & $30 \mathrm{~d}$ & $4.4 \mathrm{e}$ & 0.98 & $44 c$ & 157 & $6,235 \mathrm{~d}$ \\
\hline 10 & $\begin{array}{l}22 \text { Jan., } \\
16 \text { Feb., } \\
9 \text { Mar. }\end{array}$ & $\begin{array}{l}88 \\
113 \\
134\end{array}$ & $\begin{array}{c}\text { Basal } 2 \\
\text { leaves }\end{array}$ & $\begin{array}{l}1.5 \\
3.0 \\
9.0\end{array}$ & 4.3 & 5.5 & 8.8 & 10.0 & $10.6 \mathrm{de}$ & $18.1 \mathrm{de}$ & $33.7 \mathrm{e}$ & $12 \mathrm{f}$ & $4.1 \mathrm{e}$ & 0.95 & $68 \mathrm{a}$ & 156 & $6,957 \mathrm{~d}$ \\
\hline SE (of a $\mathrm{m}$ & & & & & & & & & 2.9 & 4.6 & 4.5 & 1.5 & 0.5 & & 2.6 & & 814.8 \\
\hline Grand mear & & & & & & & & & 37.9 & 62.3 & 76.4 & 34 & 9.0 & & 36.0 & & 4933 \\
\hline CV\% & & & & & & & & & 15.5 & 14.7 & 11.7 & 9.1 & 11.9 & & 14.3 & & 16.5 \\
\hline
\end{tabular}

$\mathrm{q}$ Days after planting.

${ }^{\mathrm{r}}$ For disease symptoms for first spray.

s Disease severity estimated from logistic progress curves.

${ }^{t}$ Disease severity is percent leaf tissue with symptoms of GLS.

"Standardized area under disease progress curve.

${ }^{\mathrm{v}}$ Infection rate $\times 100$, calculated by regressing the logistic transformation on time (DAP).

${ }^{\mathrm{w}}$ Coefficient of determination.

${ }^{x}$ Calculated from logistic progress curves.

${ }^{y}$ Mean within a column having letters in common do not differ statistically $(P \leq 0.05)$ according to Duncan's multiple range test.

${ }^{z}$ Disease first observed 53 DAP, anthesis occurred 78 DAP, and physiological maturity at 153 DAP. 
John Wiley \& Sons, New York.

5. Eik, K., and Hanway, J. J. 1966. Leaf area in relation to yield of corn grain. Agron. J. 58: 16-18.

6. Fry, W. E. 1978. Quantification of general resistance of potato cultivars and fungicide effects for integrated control of potato late blight. Phytopathology 68:1650-1655.

7. Kranz, J. 1987. Measuring plant disease. Pages 36-50 in: Experimental Techniques in Plant Disease Epidemiology. J. Kranz and J. Rotem, eds. Springer-Verlag, New York.

8. MacVicar, C. N. 1991. Soil classification. A taxonomic system for South Africa. Memoirs on the Agricultural Natural Resources of South Africa No. 15. Dept. Agric. Develop., Pretoria, South Africa.

9. Rivera-Canales, J. M. R. 1993. Yield losses, chemical control and epidemiology of fungal leaf blights on seed corn in Iowa. Ph.D. thesis. Iowa State University, Ames.

10. Smith, K. L. 1989. Epidemiology of gray leaf spot of field corn (Zea mays L.) caused by Cercospora zeae-maydis Tehon \& Daniels. $\mathrm{Ph}$.D. thesis. University of Maryland, College Park.

11. Stromberg, E. L. 1986. Gray leaf spot disease of corn. Va. Co-op. Ext. Serv. Publ. 450-072,
Virginia Polytechnic \& State University, Blacksburg.

12. Vanderplank, J. E. 1963. Plant Diseases: Epidemics and Control. Academic, New York.

13. Ward, J. M. J., Birch E. B., and Nowell, D. C. 1994. Grey leaf spot on maize. Coordinated extension. Maize in Natal. Cedara Agric. Develop. Inst., Pietermaritzburg, South Africa.

14. Ward, J. M. J., and Nowell, D. C. Epidemiology and management of grey leaf spot disease, a new disease of maize in South Africa. In: S. Afr. Maize Breed. Symp., 10th. (In press.) 